\title{
Tętniak prawdziwy po bezobjawowym zawale dolnej ściany lewej komory jako podłoże ciężkiej wtórnej niedomykalności mitralnej
}

\author{
A true aneurysm after asymptomatic inferior wall myocardial infarction \\ of the left ventricle as the basis of severe secondary mitral regurgitation
}

\author{
Barbara Zając ${ }^{1}$, Ewa Szymczyk ${ }^{1}$, Tomasz Kaszczyński ${ }^{2}$, Jarosław D. Kasprzak ${ }^{1}$, Arkadiusz Ammer ${ }^{2}$, \\ Daniel Steter ${ }^{2}$, Tomasz Stanisławski ${ }^{2}$ Paulina Wejner-Mik ${ }^{1}$, Piotr Lipiec ${ }^{1}$, Grzegorz Religa ${ }^{2}$ \\ ${ }^{1}$ Katedra i Klinika Kardiologii Uniwersytetu Medycznego w Łodzi \\ ${ }^{2}$ Oddział Kardiochirurgii Wojewódzkiego Specjalistycznego Szpitala im. W. Biegańskiego w Łodzi
}

Pacjentka w wieku 62 lat, bez wywiadu w kierunku choroby wieńcowej, z objawami niewydolności serca II (okresowo do III) klasy według NYHA, zgłosiła się na oddział kardiochirurgii w celu wyznaczenia planowego terminu operacji istotnej niedomykalności mitralnej (MR, mitral regurgitation), zdiagnozowanej miesiąc wcześniej. W badaniu przedmiotowym stwierdzono tachykardię 120/min, głośny szmer skurczowy nad koniuszkiem serca promieniujący do lewej pachy oraz cechy zastoju w krążeniu płucnym. W EKG ujawniono tachykardię zatokową 120/min, patologiczne załamki Q i ujemne załamki T w odprowadzeniu II, III i aVF.

W badaniu echokardiograficznym uwidoczniono dyskinetyczny tętniak lewej komory (LV, left ventricle), z wrotami o szerokości 28 mm obejmujacymi 1/2 podstawnej ściany dolnej (głębokość tętniaka $39 \mathrm{~mm}$ ) z towarzyszącą skrajnie ciężką MR - IV stopnia (prędkość przepływu przez zastawkę $1,5 \mathrm{~m} / \mathrm{s}$, skurczowe odwracanie przepływu w żyłach płucnych, talia fali zwrotnej $10 \mathrm{~mm}$, długość przedniego płatka $28 \mathrm{~mm}$ ), na tle istotnej restrykcji obu płatków w mechanizmie poszerzenia pierścienia i pociągania aparatu podzastawkowego przez poszerzoną LV (wymiar końcoworozkurczowy LV 60 mm), z frakcją wyrzutową LV 38\% - MR typu IIlb według klasyfikacji Carpentiera (ryc. 1A-C). Ponadto stwierdzono cechy ciężkiego nadciśnienia płucnego przy prawidłowej funkcji skurczowej prawej komory (SPAP 85 mm Hg, ACT 67 ms, TASPE 22 mm, S' RV 12 cm/s). Dodatkowo uwidoczniono niewielką ilość płynu w worku osierdziowym (rozwarstwienie blaszek osierdzia do $9 \mathrm{~mm}$ ) oraz umiarkowaną ilość płynu w obu jamach opłucnych.

W koronarografii uwidoczniono zamkniętą gałąź tylno-boczną dominującej prawej tętnicy wieńcowej oraz niekrytyczne zmiany miażdżycowe w pozostałych naczyniach wieńcowych.

Ze względu na obraz echokardiograficzny skrajnie ciężkiej MR i postępujące objawy niewydolności serca pacjentkę przyjęto na oddział kardiochirurgii w celu przygotowania do przyspieszonej operacji kardiochirurgicznej. Mimo intensywnej farmakoterapii niewydolności serca wciagu $48 \mathrm{~h}$ od przyjęcia obserwowano narastanie duszności do IV klasy według NYHA. Pacjentkę zoperowano w krążeniu pozaustrojowym, z użyciem kardioplegii. Śródoperacyjnie uwidoczniono zastawkę mitralną o nieco poszerzonym pierścieniu i wciagniętych płatkach oraz wrota tętniaka prawdziwego między pierścieniem mitralnym i podstawą tylnego mięśnia brodawkowatego. Worek tętniaka splikowano dwoma paskami teflonu, uzyskując jego istotne zmniejszenie. Następnie wykonano plastyke zastawki mitralnej z użyciem pierścienia Edwards Lifesciences $26 \mathrm{~mm}$. W przezprzełykowym śródoperacyjnym monitorowaniu echokardiograficznym i kontrolnym badaniu przezklatkowym potwierdzono dobry efekt zabiegu (ryc. D-F).

Powstanie tętniaka LV jest skutkiem pełnościennego zawału mięśnia sercowego. Wśród tętniaków pozawałowych $98 \%$ stanowią tętniaki prawdziwe, a tylko $2 \%$ tętniaki rzekome. Tętniaki prawdziwe ściany dolnej są rzadkie i stanowia około 8\% wszystkich tętniaków prawdziwych. Często z tętniakiem ściany dolnej LV współistnieje MR. W przypadku istotnej MR preferuje się zabieg naprawczy (w większości przypadków ciasną annuloplastyke mitralna z zastosowaniem pierścienia o 2 rozmiary mniejszego niż to wynika z pomiaru długości przedniego płatka zastawki).

Przedstawiony opis przypadku ukazuje nietypowy, bezobjawowy przebieg choroby wieńcowe z wytworzeniem tętniaka prawdziwego LV, powo dującego ciężką, przez długi czas skąpoobjawowa MR. Uwagę zwraca również fakt nagłego zaostrze nia objawów niewydolności serca, mimo intensywnego leczenia farmakologicznego i konieczność pilnego leczenia operacyjnego.


Rycina 1A. Badanie echokardiograficzne przezklatkowe (TTE, transthoracic echocardiography), projekcja koniuszkowa dwujamowa: tętniak prawdziwy ściany dolnej lewej komory (LV) (gwiazdka), widoczny istotny brak koaptacji płatków mitralnych (czerwona strzałka) i poszerzenie pierścienia mitralnego; B. TTE, projekcja koniuszkowa dwujamowa metoda kolorowego doplera: ciężka niedomykalność zastawki mitralnej, obejmująca cały lewy przedsionek, odwracająca skurczowy przepływ w żyłach płucnych; tętniak prawdziwy ściany dolnej lewej komory (gwiazdka); C. TTE, projekcja przymostkowa w osi krótkiej: tętniak prawdziwy ściany dolnej LK (gwiazdka); D. Przezprzełykowa echokardiografia (TEE, transesophageal echocardiography) 3D w trybie kolorowego doplera zastawki mitralnej od strony lewego przedsionka (LA) podczas monitorowania śródoperacyjnego po wszczepieniu pierścienia Edwards Lifesciences $26 \mathrm{~mm}$ i plastyce tętniaka LV - dobry efekt zabiegu, śladowa niedomykalność mitralna (zielona strzałka); E. Kontrolne pooperacyjne TTE, projekcja przymostkowa w osi długiej: widoczne hiperechogeniczne echa pierścienia mitralnego; wioczny obszar splikowanego tętniaka LV (czerwona strzałka); F. TEE 3D zastawki mitralnej od strony lewego przedsionka podczas monitorowania śródoperacyjneó po wszczepieniu pierścienia Edwards Lifesciences $26 \mathrm{~mm}$ i plastyce tetniaka LV widoczne echo wszytego pierścienia oraz szwy; Ao - aorta; AML - przedni płatek mitralny; PML - tylny płatek mitralny

Adres do korespondencji: lek. Barbara Zając, Katedra i Klinika Kardiologii, Uniwersytet Medyczny w Łodzi, Wojewódzki Specjalistyczny Szpital im. W. Biegańskiego, ul. Kniaziewicza 1/5, 91-347 Łódź, tel./faks +48 42251 6216, e-mail: dmbarbarazajac@gmail.com 